\title{
KELAKAR BETHOOK IN PALEMBANG MALAY LANGUAGE: A LINGUISTIC ANALYSIS
}

\author{
Susi Herti Afriani \\ School of Humanities and Communication Arts \\ Western Sydney University, Australia \\ Email: s.afriani@westernsydney.edu.au
}

\begin{abstract}
This paper examines distinctive culturally-linguistic humour and directives in Palembang Malay language (hereafter referred as Palembangnese) in Indonesia. Two transcribed samples of Kelakar Bethook (KB) in Palembangnese humour were selected. The data analyses and discussion show the uniqueness of humour and directives in KB in Palembangnese. This present research contributes to the nature of linguistics in language documentation and extends the scope of speech act research in a non-western language. This study also contributes to enhancing the linguistic-cultural theory in Eastern language and culture. This research thereby contributes to distinguishing one facet of language Malay civilization by exploring distinctive cultural-linguistic practices and promoting a wider awareness of Palembangnese culture and humour.
\end{abstract}

Keywords: affective-face theory, cultural-linguistic practices, directives, humour, Kelakar Bethook, Palembang Malay language.

\section{Introduction}

Humour and directives are two widely used communication tools in society. Palembang Malay language (hereafter Palembangnese) is a language spoken on the island of Sumatera in Indonesia. Humour plays an important role in the Palembang community and in the Palembangnese is defined as kelakar which means a joke. "Jokes refer to humorous utterances in general" (Tsakona, 2017, p. 490). Previous studies in Palembangnese have investigated Palembangnese from morphology, phonology, syntaxis, semantics and sociolinguistics analysis (Amalia \& Ramlan, 2002; Dungcik, 2017; Muhidin, 2018; Oktovianny, 2004; Purnama, 2008). However, no research has investigated Palembangnese humour and directives at the level of a discourse analysis. A large number of studies have also been conducted on directives in relation to politeness in different languages (Aslan, 2017; Atawneh, 1991; Blum-Kulka \& House, 1989; Dong, 2009; Eslamirasekh, 1993; Hassall, 2003; Hofmann, 2003; Jalilifar, 2009; Manaf, 2005; Márquez Reiter, Ganchenko, \& Charalambidou, 2016). However, to date, no research has discussed the specificity of humour and directives in Palembangnese. This paper contributes to this gap. In this paper, this study argues that humour and directives in Palembangnese are unique and vary in local culturally-specific ways. This paper seeks to address the following question.

- What are the distinctive cultural-linguistic practices in humour and directives in the Youtube video of Kelakar Bethook (KB) Palembangnese humour? 
The research data in this paper are drawn from two Youtube videos of Kelakar Bethook Palembangnese humour. Two transcripts are examined and analysed using strategies combined from Partington (2006) and Brown and Levinson (1978).

\section{Previous Studies}

Many researchers have studied directive speech acts from different perspectives including cross-cultural studies, speech act and politeness theory, conversation analysis and cognitive linguistics, and functional-typological analysis (Afriani, 2019; Aslan, 2017; Gu, 1990; Ide, 2002; Kong, 1998; Márquez Reiter et al., 2016; Matsumoto, 1988; Wierzbicka, 1985). To date, there has been little agreement on distinctive cultural-linguistic practices in Palembangnese humour and directives in Indonesia. Previous studies have reported humour research from two perspectives, the first, based on the type of research humour (Coates, 2007) and the second, based on the concept of humour (Dyck \& Holtzman, 2013). With this in mind, and extending this research, this study investigates humour and directives in KB Palembangnese humour in Indonesia, in particular, it examines distinctive cultural-lingustic practices in Palembangnese humour and directives. Since research in the Palembang Malay Language has never analysed humour data, this paper, aims to show one of the most popular and lively natural data in Palembang society, which is referred to as the Kelakar Bethook".

Some researchers have also shown forms of analysis in humour, specifically those related to oral conversation narratives (Tsakona, 2017), stand-up comedy and performance transcripts (J. Rutter, 1997; Jason Rutter, 2000, 2001); stand-up comedy (Belanger, 2017; Greenbaum, 1997; Kohlmann, 2014) and humour analysis and media discourse analysis (Chovanec \& Ermida, 2012). This study conducted an analysis using affective-face theory (Partington, 2006). In reaching certain rhetoric and achieving pragmatic goals, Partington (2006) examines and analysing strategies referred to as "laughter talk", for example points that can threaten someone's face and or points that are argumentative.

\section{Data and Methodology \\ Data}

Data were gathered by downloading videos of Kelakar Bethook Palembangnese humour via Youtube. The videos are produced by Palembang Studio 42 Television. Ten videos were transcribed, and then translated from Palembangnese into English; two randomly selected video transcripts were analysed. The first, "Humorous kit of Palembangnese people (a guessing game)", was published on 25 July 2015. This is a comedy conversation between Yai Najib and Cek Eka (Palembangnese people who are on holiday in Bali in Indonesia). The first transcript comprises 3675 words; it includes notations, cultural explanations, English translations, an overview of the distinctive main features, the specificity of humour and directives, and a summary of the KB1. Indications of where laughter occurs are also included by the word "laughter" in square brackets. The second KB Palembangnese humour "Yai Najib and Cek Eka act deaf" was published on 27 July 2017. The second transcript contains 4209 words, and the same features are included as on transcript one. 


\section{Methodology}

In order to identify the distinctive cultural-linguistic practices used to perform humour and directives in Palembangnese in the two KB transcripts, this study established a framework for analysis; the framework combined the theories of Partington (2006), and Brown and Levinson (1978). For the purpose of analysis, every script in each transcript was examined to identify the distinctive features and specificity of humour and directives in Palembangnese. "Script" is taken as a neutral term among the various proposals (e.g., frame, schema, daemon, etc) and thus does not have exactly the common meaning of the term A1. A Script is defined as a complex of information associated with a lexical item (Attardo, 2001, p. 53).The scripts segmentation in this $\mathrm{KB}$ data is based on the distribution of character utterances. For example, in KB1, there are two main characters namely Yai Najib and Cek Eka. From here, scripts are made sequentially based on the order of speech of the two characters in KB. In short, the number of scripts will match the number of utterances from these two characters. While humour frequency in KB data is determined based on the emergence of speech frequency which is identified as humour in Palembangnese. In this paper, the occurrence of humour frequency is determined from all the scripts that exist in one KB transcript.

Furthermore, both KB data sets are discussed primarily using Partington's (2006) affective face theory and affiliation alignment concept.

"Affiliation is used to mean the expression of solidarity with another participant on an effective, interpersonal plane, whereas alignment means communicating agreement with what another person has said, that is, approval of the opinions and sentiments he or she has expressed" (Partington, 2006, p. 18).

This affiliation alignment concept was combined with the concept of public performance, power, and face to examine Palembangnese humour in the KB data (data spoken language in Palembangnese). Public performance is defined here as an action in front of a public audience because "performances are action" (Schechner, 2017, p. 2). "Power" in this present study refers to "social power" which is defined in terms of 'authority' or 'the social distance' (D) of the speaker and the hearer as a symmetric relation (Brown \& Levinson, 1987). "Face" means honour, self-esteem, and public self-image. Each participant has two needs in every social process: the need to be appreciated and the need to be free (not bothered). The first need is the so-called positive face, while the second is the negative face, (Brown \& Levinson, 1978).

\section{Findings and Discussion}

The first script, KB 1, provides a context of the humorous skit. The situation is a comedy conversation between two friends who are on holiday in Bali. The main characters are Yai (male character) and Cek Eka (female character). In Palembangnese, Yai denotes a grandfather. But in this context, Yai Najib is the name of a person. Cek in Palembang is someone who has a noble title. In this case, Cek Eka is a woman named Eka, who has a peerage. The script shows the distinctive greeting word in Palembangnese. The word $O i$ in the utterance Oi Ya Saman is a greeting word for attention. Ya Saman refers to the legendary song title from the city of Palembang. This song has lyrics in Palembangnese and is well 
known to Palembang people. The song is often sung at weddings, thanksgiving, even at government events such as at the 26th Sea-Games closing event in Palembang City. Ya Saman itself means "amazing things". This word can be for positive things, for instance "Ya Saman cantiknyo gadis itu" (Ya Saman how beautiful the girl is), or things that are negative, "Ya Saman, how bad the children are" (Ya Saman, how bad the children are). Each meaning can be produced depending on the pronunciation in Palembangnese. Ya Saman has Islamic cultural roots, originating from the name of a Muslim-born cleric named Sheikh Muhamamd Samman ( Kurnia \& Prandansari, 2018). In KB 1 “Oi Ya Saman! How cold it would be if we dive at this Bali Kute beach, Yai!" is an opening conversation between two friends.

The relationship between speakers (Yai Najib) and addressees (Cek Eka) is described as a close friend $(+\mathrm{D})$, with the same power $(\mathrm{P})$ and the conversation topic is low in imposition (R). This background is important as "in order to understand how joking can simultaneously express aggression and build rapport, researchers need to view jokingtelling, punning and teasing in relation to power, solidarity and distance and in light of the principles of politeness and cooperation" (Norrick as cited in Hay, 2001, p. 57). To pass the time, Yai and Cek Eka start to play tebak-tebakan (a guessing game). There is debate in this story, fellow competition, and informal situations. The script 1, followed by script 2-7 is an invitation for playing "a guessing game", "game requirements", and their agreement. The current study found humour and directives in the transcript (See Appendix) below, which is followed by a detailed analysis. Table 1 shows an overview of the distinctive main features on each script and the frequency of the important characteristics:

Table 1. An overview of Data 1 Kelakar Bethook Palembangnese Humour (KB1).

\begin{tabular}{|c|c|c|c|c|c|c|}
\hline $\begin{array}{c}\text { Important } \\
\text { Characteristic } \\
\text { s of KB1 }\end{array}$ & $\begin{array}{l}\text { Directive } \\
\quad \mathrm{s} \\
\text { Frequenc } \\
\mathrm{y}\end{array}$ & $\begin{array}{l}\text { Humours } \\
\text { Frequenc } \\
\mathbf{y}\end{array}$ & $\begin{array}{c}\text { Vocative } \\
\text { s }\end{array}$ & $\begin{array}{c}\text { Script } \\
\text { Collisio } \\
\text { n }\end{array}$ & $\begin{array}{c}\text { Role } \\
\mathrm{s}\end{array}$ & $\begin{array}{c}\text { A culture } \\
\text { standard/exaggerati } \\
\text { on }\end{array}$ \\
\hline $\begin{array}{l}\text { Script 1- } \\
\text { Script } 77\end{array}$ & 8 & 10 & 1 & 1 & 54 & 3 \\
\hline
\end{tabular}

As table 1 shows, in KB1 humour occurred ten times and directives occured eight times, followed by other features such as vocatives (once), script collision (once), roles of male and female characters (54 times), and some exaggeration utterances (three times). One of the interesting features of "start of playing the game" in Palembangnese is found in script 12. The word usit is a distinctive cultural practice in Palembangnese. It is a cultural sign when two people or a group of children would like to play a game.

From table 1 above, we can see that humour is located at script 14, 37, 25, 27, 56, 66, 70, 72, 74, and 75. Overall, the specific humour found in the KB 1 are "jokes", "teasing" and "fantasy humour". For instance, the humours in scripts 25, 27, 66, 72, and 74.

Script (25) "Yaa... jawaban dak bemutu" (Yaa...your answer is not qualified)

Script (27) "Ya, nyebor caknyo ni" (It seems that you will dive)

Script (66) "Ngitung dulu satu duo tigo Nah...ngadep sano!" (I will count in advance.

One, two, three...nah. Face in direction!)

Script (72) "Eya...Mamat nak bejilbab" (Eya...Mamat will wear a hijab)

Script (74) "Mamat nak bejilbab" (Mamat wants to wear a hijab) 
Script 25 and 27 depict teasing. "Teasing builds solidarity precisely because the potential of an utterance to threaten or wound is deactivated by context but, especially among non-intimates who can make misguided assumptions about context and fellow participants, non-intentional reactivation is a constant danger" (Partington, 2006, p. 146). "A tease is a Face-Threatening Acts (FTA) performed (apparently) in non-bona-fide mode in that it violates the Gricean maxim of quality (that is, sincerity)" (Partington, 2008, p. 773). In this context, this data further supports the idea of defining teasing, as proposed by Partington (2008, p. 773) "it is insincerity in that it is (supposedly) not meant to really threaten the hearer's; it is (apparently) a fictional face attack". Since it is a fictional attack, it means that we can identify the seriousness or weightiness of a particular FTA. Based on Goffman's concept of face, Brown and Levinson (1978) built a theory about relationship intensity called FTA in the language of politeness. The intensity of FTAs is expressed by three social parameters; power, social distance, and rate of imposition.

"For each of FTA, the seriousness or weightiness of a particular FTA is compounded of both risk to speaker's face and risk to hearer's face, in a proportion relative to the nature of the FTA. However, the way in which the seriousness of a particular FTA is weighed seems to be neutral as to whether it is speaker's or hearer's face that is threatened or in what proportion" (Brown \& Levinson, 1978, p. 76).

In KB 1, the term teasing is applied in a Palembangnese phenomenon. This actually implies "mockery, taunting, or any verbal abuse short of physical violence" (Partington, 2008, p. 772). However, script 25 refers to Cek Eka's response as a result of mocking Yai Najib's answer that started when they played "a guessing game"; Cek Eka asks whether the snake does not have feet to Yai Najib (male character). His answer is "if it is a creation of God, it is truly like that". This answer is not considered argumentative nor scientific by Cek Eka. Then, she mocks Yai Najib (her interlocuter) by uttering script (25). Yai Najib further argues that "if the snake could run, it means they have feet". Again, Cek Eka continues teasing in the script (27). As shown in the previous scripts, the loser will dive into the cold water at Kute Bali beach. The phrase "your answer is not qualified" in the script (25) is a face threatening activity (Brown \& Levinson, 1978), in a certain context.

What is surprising is that Yai Najib (the hearer's "face"/self-esteem) is laughing in the script 28 "(Laugh), wait a minute. Give me time". This means that this FTA has not threatened his face, because they are friends (closed distance), they are equal in power, and they are "playing game" (low in rate of imposition). Hence, it is "a fictional face attack" (Partington, 2008; p. 773), or may be considered as affiliation alignment. "Affiliation is used to mean the expression of solidarity with another participant on an effective, interpersonal plane, whereas alignment means communicating agreement with what another person has said, that is, approval of the opinions and sentiments he or she has expressed" (Partington, 2006, p. 18).

In this informal discourse, Cek Eka (female character) exaggerated her intonation and had a laugh in her voice, as shown in the script (27) "Ya, it seems that you will dive!" (they were laughing). The example then confirms that Cek Eka's teasing is not serious - not a "bona-fide face attack" (Partington, 2008, p. 774), and the script at (25) and (27) is intended to make the "audience" laugh. The audience laughs because they can understand the humorous purpose. Recipient laughter can be seen as a "signalling affiliation alignment". In this case, "affiliation" can be interpreted as a form of expression of solidarity with other 
participants, while "alignment" means a form of communication agreement with what others have said. This is a form of "approval" and opinion conveyed by the other people. The power to create an "affiliation" means laughter is a very powerful tool in creating group solidarity. On the other hand, the power to create "disaffiliation" can cause a person or group to feel that they are not part of a particular group and can result in someone becoming embarrassed and experiencing FTAs (Partington, 2006).

In this context, this message includes a specification agreed upon by the addresser and addressee in the context of Palembangnese communication. According to Sperber and Wilson (1995), it is "relevance". In this sense, the interlocutors (audience) pick something which is relevant to what is being conveyed by the speaker. Specifically, the audience of Palembangnese context can always identify the indeterminacy or underspecification. Through this, they can choose only what they deem relevant in the context of Palembangnese humour.

Fantasy humour occurs in Palembangnese. Script 66 was identified as fantasy humour, and it typically occurs in informal and casual conversation among friends (Hay, 2001). In this KB1 context, script (66) "I will count in advance. One, two, three...nah. Face in direction!" is uttered by Yai Najib to entertain Cek Eka as his interlocutor, but also for the audience. The script 66 reveals that situations can be made humorous in Palembangnese culture. This situational context is funny as the script 67 illustrates Cek Eka's complaint (funny), followed by the script 68 which describes the climax of the guessing game. In this script, Yai Najib acts as if he is a woman who wears hijab. This action is humorous because the audience recognises this as a universal issue. In Malay culture and Islamic context, it is impossible for a man to use a head covering (hijab), since only women are required to do so. "Mamat/Slamat" (a boy as the main character in the story of guessing game) becomes the character who made this situation become funny. "Humour reception and evaluation are notoriously hugely dependent on context and whether or not the audience is primed for laughter" (Partington, 2006, p. 117).

Surprisingly, another type of humour (satire and joke) in Palembangnese is evident in KB1; in the script (72) and script (74). These two scripts sound repetitive and have the same meaning. Yai Najib repeats these two utterances because he tries to make a joke. A difference between script (72) and script (74) is that script (72) is satire, and script 74 is a joke. Script (72) "“Eya...Mamat will wear a hijab" is satire. Some researchers claim satire as humorous discourse (Hight, 2010; Malmqvist, 2015; Marzouki, 2015; Maslo, 2016; Simpson, 2003; Wallis, 2016; Wood, 2013). In Palembangnese language and culture, satire is closely associated with subtle innuendos and sarcasm, or speakers taunting listeners in certain situations. For instance, "majal nian kau ini" (greedy you are this), is a form of satire to people who are very greedy (Purnama, 2008). However, in the script (72), this satire is used rather than an action to make the audience laugh. The word nak (will) in Palembangnese refers to "someone" who will do it. In Palembangnese context, this script is funny as no man uses a hijab in real life situations; because men who use the hijab will be considered "effeminate" or considered to be mocking Islam.

Furthermore, script (74) "Mamat wants to wear a hijab" uttered by Yai Najib is clearly a joke. The difference between a joke and lie is that telling a joke is an act of cooperation, whereas telling a lie is a deception (Partington, 2006). Hence, Yai Najib's action in the script (74) is a cooperation to make people (audience) laugh. This is funny since Cek Eka and the audience understand the message of the utterance and Cek Eka's response in the following script shows the "recipient" laughter. "You are crazy. You deserve to be killed. Ah...You are 
really crazy, Yai. Ea...yes. I am finished. Ai dah" (annoyed expression). One of the issues that emerges from these findings is the distinctive cultural-linguistic practices in Palembangnese humour that are located in a unique way and need further context and cultural explanation (See details in Appendix Transcript KB1).

Strong evidence of directives was found when the two friends' request or command one another. It reveals that the closer the relationship is, the speaker can easily ask the interlocutor to do something. Directives, based on the speaker's intention, include speech acts of requesting, begging, appealing, suggesting, and advising (Searle, 1976). In KB1, directives can be seen in the script 2, 8, 9, 12, 28 (requests) and script 3, 66 and 70 (commands).

Requests and commands are critical to the foundation and continuance of interpersonal relationships. In addition, compared to the other types of directives (e.g., advice and suggestion), they represent a cost to the interlocutor and a profit to the speaker (Mauri \& Sansò, 2011; Young Lee \& Ogi, 2017). It can be seen from the data in table 1 that requests in KB 1 significantly out number commands; the results obtained from scripts 2, 8, 9,12 , and 28 are below.

$\begin{array}{ll}\text { Script (2) } & \text { "Da mak ini be, Cek Eka Anten-anten nunggu ari siang kito maen } \\ & \text { tebak-tebakan be" (Let us play a guessing game while killing time). } \\ \text { Script (8) } & \text { "Amen samo-samo idak tetebak?" (How if we can't guess together?) } \\ \text { Script (9) } & \text { "Samo-samo nyebor" (Let us dive together). } \\ \text { Script (12) } & \text { "Usit dulu" (Let us do scissors, paper, rock before we start) } \\ \text { Script (28) } & \text { "He..he (laugh). Kagek dulu iyo enjuk waktu dulu" (Wait a minute. } \\ & \text { Give me time) }\end{array}$

As mentioned above, the relationship between speakers (Yai Najib) and addressees $($ Cek Eka) is as a close friend (+D), with the same power $(\mathrm{P})$ and the conversation topic is low in imposition (R). Softening illocutionary power is also done by realising do the FTA on record with redressive action with positive politeness (PP) in the form of politeness substrategies as follows: first using identity markers as members of the same group, as seen in script 2, 8 and 9. The word "kito" in the script 2 used by Yai Najib (male character) is a speech used to soften illocutionary power. In this case, it translates to "let us". This is also seen in the word "samo-samo" which means "together" and also refers to "we". Another example appears in the form of the greeting "samo-samo" in script 9, and 12 and in the form of a strategy "sambil bergurau" (joking) in script 28.

With this in mind, it can be concluded that speakers in this case use the same identity markers as groups which use the first plural person pronoun kito (we), as seen in examples (8) and (9). The pronoun which is interpreted as samo-samo/kito (we) in the script (8) and (9) implies that the speaker identifies himself as a member of the group with the speaker so that there is a reason for the speaker to ask or instruct the speaker to do something. Moreover, the first plural pronoun "we" causes a softening effect on illocutionary power so that speech feels polite. Basically, the speech form and the level of continuity of speech in scripts 2, 8, 9, 12 , and 28 are the same. However, the form and degree of continuity of the request for the five utterances above is distinguished slightly by the phrase amen (if) in the form of the question how if we cannot guess it together? adds to the softening effect of illocutionary power, so that speech (8) is more polite than other utterances. 
With respect to commands, Table 1 presents commands found in scripts 31, 66, and 70. The utterances from those scripts are shown below:

Script (31) “Nyebor ye!" (You dive, yeah!)

Script (66) “...Ngadep sano!" (... Face in that direction!)

Script (70) “... Bebaleklah!” (... Face in this direction, Cek Eka!)"

In scripts 31, 66, and 70 in this study, the five politeness strategies postulated by Brown and Levinson (1978) are evident. One of the politeness strategies is bald on record (BOR). Thus, this symptom can be interpreted that the forms of speech used by Yai Najib and Cek Eka in KB 1 to express directives in the Palembangnese reflected the bald on record strategy. The choice of this strategy relates to muka notion (face's notion). Muka (face), which refers to one's self-esteem, is also found in Palembang culture. The concept of kehilangan muka (lost face); has two personalities muko duo (two faces), and if someone does not have shame, then he will be called muka tebal (face thickness).

The examples mentioned in scripts 31, 66, 77 are BOR strategies realised in an imperative form. Except for the small variations, the speech form and the degree of continuity of the speech are relatively the same. The small difference between examples 31, 66, and 70 is the presence of other strategies, in this case, the bald on record strategy is accompanied by a strategy for using the same group identity markers in the form of Cek Eka kinship, the script (70) is an example of the realisation of a bald on record strategy in the complete imperative form whose focus is softened by the use of greetings of kinship. The use of the greeting form cek creates a softening effect on illocutionary power so that speech is polite. Speech 31 is also the realisation of bald on record in an imperative form with the passing of phrases whose focus is softened. The word in ya (yeach) in the phrase "You dive, yeach!" in the text script 31 softens illocutionary power so that speech feels polite. Inference that can be drawn from the fluctuating occurrence of bald on record in the imperative form with phrase drift is that forms of more direct speech strategies tend to be used in situations containing low face threatening levels, which are characterised by a close relationship (+ D) and demand non-threatening face $(\mathrm{R})$. In addition, this bald on record strategy is used to speak to people who are already familiar, such as Yai Najib and Cek Eka, and has a softening effect on the illocutionary power of speech that feels polite.

This analysis of KB 1 has shown a variety of Palembangnese humours and directives in Palembangnese including fantasy humours, teasing and joking, and directives in the form of commands and requests. The evidence from this study suggests that Palembangnese humours are distinctive because they are contextual and some of them cannot be translatable. Hence, cultural explanation is needed to fully understand the meaning and situations. The following section explains KB3.

The first script in Video 3 entitled "Yai Najib and Cek Eka act deaf" is a background knowledge of transcript 3 Kelakar Bethook Palembangnese humour (hereafter referred as KB3). The script provides some background knowledge to the audience. A husband and wife who are deaf just went to the doctor, and the wife began to talk. A linguistic practice in the first script is found in the utterance "I already told you"; although the form of the utterance is a declarative, the function is imperative. This means that first, there is a competition.

The competition here refers to the man who needs to be right all the time, but the wife proves that she also can be right. In this context, the issue is related to their condition of 
deafness, and also there is a gender background here in the utterance. The wife reminds the husband that she is right, and she has shown the capacity to understand the problem. Although the Palembangnese community has a patriarchal culture, the wife has control of finances. This is a distinctive cultural practice in Palembangnese. The gender background thus shows a wife at home functions as a "domestic woman" and also has competency to manage money and speak up. A detailed conversation (see Appendix Example KB3) and analysis shown below:

The first step of analysis examined the distinctive features and the specificity of humour in KB3. Table 3 (below) summarises the distinctive main features. The table illustrates the frequency of the important characteristics occurred in each script.

Table 3a. An overview of Data 3 Kelakar Bethook Palembangnese Humour

\begin{tabular}{|c|c|c|c|c|c|c|}
\hline $\begin{array}{l}\text { Important } \\
\text { Characteristic } \\
\text { s of KB } 3\end{array}$ & $\begin{array}{l}\text { Directives } \\
\text { Frequenc } \\
\text { y }\end{array}$ & $\begin{array}{l}\text { Humour } \\
\text { Frequenc } \\
\mathrm{y}\end{array}$ & $\begin{array}{l}\text { Vocative } \\
\text { S }\end{array}$ & $\begin{array}{l}\text { Script } \\
\text { collisio } \\
\mathrm{n}\end{array}$ & $\begin{array}{l}\text { Role } \\
\mathrm{s}\end{array}$ & $\begin{array}{l}\text { A culture } \\
\text { standard/Exaggeratin } \\
\mathrm{g}\end{array}$ \\
\hline $\begin{array}{c}\text { Script 1-Script } \\
81\end{array}$ & 15 & 15 & 8 & 1 & 36 & 5 \\
\hline
\end{tabular}

It can be seen from the data in the table 3a that the occurrence of the wife reported significantly more than directives and humours. What is interesting in this data is that humours and directives have similar occurrences (15 times) out of 81 scripts, followed by several features, such as vocatives (8 times), script collision (once), and some exaggeration styles (5 times). Interestingly, humour frequencies reveal the specificity of humour. For example, a pun (play of word), and irony joking. Five scripts contain humour that shows distinctive-linguistic practices in Palembangnese. As mentioned above, example 3 illustrates the background of power (a husband and a wife relationship), directives, competitions and gender. The first script is clearly shown the interactional pattern of Palembangnese marriage, and also describes typical "wife talk". As mentioned earlier, a woman has a role in the household and they tend to talk too much at home,

In KB3, 15 frequencies of humour were found in 15 scripts. The first example of specific humour was "irony humour" or Parodi humour (Ross, 1998). Parodi is imitation which entertains through being sarcastic. Parodies consist of two ranges, namely subtle irony, and satire, which is more sarcastic. Script 9 in KB 3 is a subtle irony and depicts a conversation between the husband (Yai Najib) and the wife (Cek Eka) as a form of kelakar (humour in Palembangnese). The wife is joking with irony to her husband's laughter. It is a joke because the husband (Yai Najib) considered that a quarter of million rupiah (Rp. 250.000) is significant. It is called irony because the wife said that "we never have problem about money, ye!" The utterance by the wife (Cek Eka) "just remember that both of us are such absent-minded people" means that both of them have a problem managing money. It is an irony and can be a parody since the wife quips with the husband. Thetwo main characters in KB3 (the wife and the husband) are targeting silly humour that comes from being absent-minded. Therefore, people will love that other people laugh. The script 9 in the $\mathrm{KB} 3$ is also translatable as the acts of the husband and the wife are universal. 
Distinctive humour practices are also found in scripts 16, 18, and 21. All of them are pun-play of words, as shown below:

example,

Script (16) "Misalnyo Aku, mama tolong buatke aku kopi sianida catat?" (For note?").

Script (18)

Script (21) could you please make a Sianida coffee. And then I make a

\author{
"hahahaha (tertawa)" (hahahaha (Laughter)). \\ "Jangan Sianida. Sianita bae" (It should not Sianida, just Sianita).
}

These plays of words make the utterances sound funny. For instance, in script 16, the husband (Yai Najib) requests his wife to make a coffee. "Could you please make a Sianida coffee?" and script 17 shows the wife's response. "Do you really like it? I will make it first if you like", and script 18 shows the husband's laughter. Script 16 is funny because "Sianida coffee" is not real coffee and is a distinctive cultural reference. Sianida coffee is a symbol of "a poison coffee" (see the background of Sianida coffee in footnotes 17 in KB3 transcript). Hence, Sianida coffee is funny. This Palembangnese humour is unique and culturally distinctive. It is based on the "story of Sianida" and the controversies circulating in relation to the planned murder of Wayan Mirna Salihin's that resulted in hisdeath in 2016. Mirna was being poisoned while drinking Vietnamese-style iced coffee. Both of the husband and the wife laugh because they understand that it was impossible to drink Sianida coffee, since the coffee is a symbol of killing someone. Furthermore, the husband's utterance "Jangan Sianida, Sianita bae", in the script 21 shows a pun-play of word. Sianida refers to "a poison coffee", while Sianita refers to symbol of woman's name in Indonesia. This humour is not translatable because Sianida coffee and Sianita (a woman's name) are not universal and in order to understand thus humour, the readers/audience need a text-reference.

Surprisingly, taboo breaking was found in the script 36 to show another specificity of humour in Palembangnese. Through this script, the husband (Yai Najib) said "I can still have two girlfriends". This utterance is funny since it is actually a joke between the husband and the wife. It is taboo because it is not appropriate within Palembangnese culture. As mentioned earlier in the research context chapter, Palembang people are part of Islam and Malay culture. In Islam and Malay culture, a husband is not allowed to have a "girlfriend" (a woman outside marriage). It is considered haram. Haram is a concept of what is definitively forbidden by Allah SWT (God). It can be a good behavior or objects. From a linguistic point of view, the word "haram" is interpreted as "prohibited", or "breaking the law" (Wehr, 1979, p. 171). From the perspective of Islamic law, if a Muslim commits haram they will be punished, both in the world and hereafter, but will be rewarded if they can avoid it. However, a husband in Islam and Malay culture is allowed to have more than three wives as long as he can treat the women well and fairly (Alqur'an, surah An-Nisa verse 4). This humour is not translatable because this is a distinctive-cultural reference. This finding further confirms one of the types of humour proposed by Ross (1999). Humour related to violations of things that are considered taboo. This humour violates things that are considered sacred or prohibited by religion and culture of society, which includes sex, death and religion.

Another unique humour found in KB3 is a perfect term kuamborke in 'script 19. This utterance is delivered by the wife (Cek Eka) as a response to her husband's laughter. The perfect term kuamborke means that she will not write notes, but she will throw all notes. Kuamborke then is a perfect term of play of words, which in this case is referred to as 
morphology. It refers to the way an individual form of a word (Ross, 1998). With this in mind, the wife (Cek Eka) forms a word ambor with $k u$ as a subject from the word $a k u$ (I) and the suffix ke. Hence, the word ambor (throw) becomes kuamborke (I will throw them all (the notes)). This utterance and her expression are funny because it seems that she was upset and disagreed with her husband's laughter. All these actions actually target the humour because the main characters are associated with sillyness, and this humour comes from the wife and the husband who are absent-minded. As a result, people laugh because other people are laughing.

Irony/parodi humour, a pun-play of word, taboo breaking, and a morphology-play of words are all distinctive cultural linguistic practices found in KB3. In conclusion, the results in this KB3 indicate that in this example of Palembangnese humour, some is funny and translatable, as it is universal, while some are not funny since they involve uniquecultural linguistic practices. The next paragraph, therefore, moves on to discuss the distinctive cultural-linguistic practices in Palembangnese directives in Indonesia.

As mentioned in the literature review, directives are speech acts in which a speaker asks a listener to do something, for example, requesting, commanding, and questioning (Searle, 1969). The data in KB3 show that commands, advices, requests categories are included in the term of directive speech act. Interestingly, in the interaction with the husband and the wife's utterances, a command can be seen as the most frequent category of directives (11 times out of 15 directives). Commands are critical to the foundation and continuance of interpersonal relations. A command also represents a cost to the interlocutor and a profit to the speaker (Mauri \& Sansò, 2011; Young Lee \& Ogi, 2017). However, commands in Palembangnese are located in unique cultural-linguistic ways, as shown in scripts $6,25,41,44,55,59,61,63,65,71$, and 72 .

The most surprising aspect of the data KB3 is in directives, for example in script 41 . The wife's utterance "to the back" is a directive. The structure is declarative, and the function is a command. The wife's command is a response to the husband's request in script 40. "I want to eat $o i$, yes". "To the back" is a direct speech act that provides information (Yule, 1996). This directness is in fact easy to define in this context since the relationship between the husband and the wife is equal, the distance is close, and the rank of imposition is low. This text reveals that if the commands are associated with language politeness strategies (Brown \& Levinson, 1978), these commands are a form of BOR strategy; in this case it is realised in an imperative form, both complete and imperative imperatives with the release of phrases (Trosborg, 1995, pp. 200-205). The strategy is used in scripts 6, 25, 41, 44, $55,59,61,63,65,71$ and 72 . Among these eleven speech situations, the BOR strategy is most often used because it contains the lowest level of face threat, which is indicated by the parameter of power (-P) and the relationship between speakers and speakers is familiar (+ D), because they are husband and wife. For examples.

Script (25) "Em...pocok palak tula na, majuke deket tangan" (Push it close to your hand).

Script (44) "Iyo...iyo...Gancang iyo" (Yes...yes...be quick oi...yes)

Script (55) "Embekke aku roti gabeng samo cucu" (Give me gabeng bread with milk).

Script (59) “...Embekkelah! Lapar" (...Take it! I am hungry).

Script (61) “Ca...tat, kagek lupo...embek pena, kertas dulu”. (Take a note, you will forget later. Take a pen, paper first). 
The utterances in scripts (25) and (44) express the speaker's message to the speaker in a BOR complete imperative form. As can be seen in scripts (25) and (44), except for small variations, the speech form and the degree of continuity of speech 25, 44, 55 and 59 are relatively the same. The small difference between the examples that deserves attention is the presence of other strategies, which accompany the BOR strategy. In KB 3 transcript, the BOR strategy in the script (61) is accompanied by a substrategy in the form of "reasoning", in the form of "you will forget later", so that the utterance in the script (61) is a BOR strategy in complete imperative, softened in the form of "giving reason". The use of this reason can be understood as the effort of the wife (Cek Eka) to be understood as a business speaker to reduce the level of face threat (the husband's face).

The current study also found advice as another form of directives speech acts in script 12: "Therefore, if you have an intention, we will be writing it together, if I have an intention?" In Indonesian language, advice is called nasihat; it is a borrowed Arabic word. In English, advice is defined as "a directive which advocates a course of action for the benefit of the addressee, and in which the consequence compliance is desirable" (Tsui, 1994, p. 122). In Palembangnese, the form of advice, is shown in script 12, "makonyo dari itu, kalu ado kendak samo-samo dicatet, men aku bekendak?". This advice is uttered by the husband (Yai Najib) to his wife (Cek Eka). In this context, the use of the word "samo-samo" refers to the word kito (we); this can be understood as an attempt by the husband to identify himself as an imam, because husbands in Islamic households are required to show "leadership", so this advice provides a reason for husbands to ask the wife (Cek Eka) to ask or tell his wife to do something. In addition, the word "samo-samo" softens the illocutionary power so that the speech feels polite.

The feature that shows distinctive cultural linguistic practices in Palembangnese directives is the use of the expression "men aku bekendak?", which has an effect and shows the husband's attitude to be "valued" by Cek Eka (the wife). This strengthens inference, which is evident in more indirect forms of narrative strategies as in script 12 , and are used in speech situations, which contain a high level of face threat, which is indicated by parameters $(+P)$ and (-D). These forms of direct speech acts tend to be used in speech situations, which contain a low level of face threat, which is indicated by parameters (-P) and (+ D). The use of the phrase "men aku bekendak" in the directive seems to be influenced by the variety of usage of the Palembang language. This softening of illocutionary power was also carried out in the form of "seeking agreement". In this case, softening illocutionary power is also carried out in the form of seeking agreement between husband and wife; this is indicated by the expression men (if) which is located at the beginning of the speech, like the example in script 12 above.

Alwi (2018) argues that the purpose of kelakar in Palembang society is one of the ways Palembang people alleviate the hard things to be easily understood. This study argues that humour and directives in Palembangnese are distinctive because of their pattern. Directives are part of the humour itself, or in the other words, the role of directives also functions as the humour themselves, not as face threatening acts. Hence, this is shown that Kelakar Bethook then is a lively text. This is important since kelakar (jokes) show that the Palembang community has a humorous character that often produces and uses funny and humorous stories as a way of communicating in daily life. Hence, this study argues that it will be the first scientific document to maintain and sustain the humour tradition in Palembangnese. 


\section{Conclusion}

The findings that this research have presented suggest that generally (KB) Palembangnese humour contains a variety of humour and directives. The results of this study indicate that Palembangnese humour and directives are distinctive. As a result of conducting this research, this study proposes that some of humour in Palembangnese are translatable and funny. Others need a text-reference to be understood. The directives in Palembangnese show that the interesting feature of a "face" system exist in Palembangnese society, which is named and forms the accepted politeness gestures. They are expected and permissible. This paper has provided the evidence for the assertion of a unique linguistic operation of Palembangnese culture. There is a definite system of face/teasing and solidarity which performs, almost in a ritualistic way, identity and relationship.

\section{Acknowledgements}

The paper is part of the PhD thesis of Susi Herti Afriani, who supervised by Associate Prof. Robert Mailhammer, Dr. Adrian Hale, and Associate Prof. Anna Christina Pertierra. We would like to thank School of Humanities and Communication Arts, Western Sydney University who sponsored this paper to be presented at the $16^{\text {th }}$ International Pragmatics Conference in Hong Kong, 9-14 June 2019 and Dr. Susan Mowbray (Academic literacy advisor GRS WSU) who has read the first draft of this paper.

\section{Bibliography}


Afriani, S. H. (2019). Linguistic Politeness in Palembangnese Directives in Indonesia and Its Implications for University Teaching and Learning. Paper presented at the Eleventh Conference on Applied Linguistics (CONAPLIN 2018).

Amalia, D., \& Ramlan, M. (2002). Bentuk dan pemakaian" Baso Palembang Alus" di kota Palembang (Form and The Use of Baso Palembang Alus inPalembang city). [Yogyakarta]: Universitas Gadjah Mada,

Aslan, E. (2017). The impact of face systems on the pragmalinguistic features of academic email requests. Pragmatics and Society, 8(1), 61-84.

Atawneh, A. M. A.-H. (1991). Politeness Theory and the Directive Speech Act in ArabicEnglish Bilinguals: An Empirical Study. (Doctoral), State University of New York at Stony Brook,

Attardo, S. (2001). Humorous Texts : A Semantic and Pragmatic Analysis: Berlin/Boston : De Gruyter, 2001.

Belanger, J. (2017). Speaking Truth to Power: Stand-Up Comedians as Sophists, Jesters, Public Intellectuals and Activists. ProQuest Dissertations Publishing,

Blum-Kulka, S., \& House, J. (1989). Cross-cultural and situational variation in requestive behavior in five languages. Cross-cultural pragmatics, 123-154.

Brown, P., \& Levinson, S. C. (1978). Universals in language usage: Politeness phenomena. In Questions and politeness: Strategies in social interaction (pp. 56-311): Cambridge University Press.

Brown, P., \& Levinson, S. C. (1987). Politeness : some universals in language usage: Cambridge: Cambridge University Press.

Chovanec, J., \& Ermida, I. (2012). Language and humour in the media. Newcastle upon Tyne, UK: Newcastle upon Tyne, UK : Cambridge Scholars Publishing.

Coates, J. (2007). Talk in a play frame: More on laughter and intimacy. Journal of Pragmatics, 39(1), 29-49.

Dong, X. (2009). Requests in academic settings in English, Russian and Chinese. (Doctoral), The Ohio State University,

Dungcik, M. (2017). Kewujudan Bahasa Melayu Palembang Ditinjau Berdasarkan Segitiga Semiotik Ogden dan Richards (Kajian Semantik Terhadap Kosa Kata dalam Kamus Baso Palembang) (The Existence of Palembang Malay Language reviewed based on Semiotic Triangles of Ogden and Richards (A Semantic Study of Vocabulary in Baso Palembang Dictionary). (Doctoral PhD), University Brunei Darussalam, Brunei Darussalam.

Dyck, K. T., \& Holtzman, S. (2013). Understanding humor styles and well-being: The importance of social relationships and gender. Personality and Individual Differences, 55(1), 53-58.

Eslamirasekh, Z. (1993). A Cross-Cultural Comparison of Requestive Speech Act Realization Patterns in Persian and American English. Pragmatics and Language Learning, 4(1993), 85-103.

Greenbaum, A. (1997). Women's comic voices: the art and craft of female humor. American Studies, 38(1), 117.

Gu, Y. (1990). Politeness phenomena in modern Chinese. Journal of Pragmatics, 14(2), $237-$ 257.

Hassall, T. (2003). Requests by Australian learners of Indonesian. Journal of Pragmatics, 35(12), 1903-1928.

Hay, J. (2001). The pragmatics of humor support. In (pp. 55-82): Walter de Gruyter.

Hight, C. (2010). Television mockumentary: Reflexivity, satire and a call to play: Manchester University Press Manchester/New York. 
Hofmann, P. J. (2003). Language politeness: Directive speech acts in Brazilian Portuguese, Costa Rican Spanish and Canadian English.

Ide, S. (2002). The speaker's viewpoint and indexicality in a high context culture. Bunka, Intaakushon, Gengo [Culture, Interaction, and Language]. Hituzi Syobo: Tokyo, Japan, pp3-20.

Jalilifar, A. (2009). Request strategies: Cross-sectional study of Iranian EFL learners and Australian native speakers. English Language Teaching, 2(1), 46.

Kohlmann, S. (2014). "So, are we good?" The emerging sensitive new man movement in the boys' club of stand-up comedy. ProQuest Dissertations Publishing,

Kong, K. C. (1998). Politeness of service encounters in Hong Kong. Pragmatics. Quarterly Publication of the International Pragmatics Association (IPrA), 8(4), 555-575.

Kurnia, A. D., \& Prandansari, N. A. (2018). Ya Saman, Lagu Legendaris dari Palembang. Retrieved from https://gelorasriwijaya.co/blog/ya-saman-lagu-legendaris-daripalembang-fghj/

Malmqvist, K. (2015). Satire, racist humour and the power of (un) laughter: On the restrained nature of Swedish online racist discourse targeting EU-migrants begging for money. Discourse \& Society, 26(6), 733-753.

Manaf, N. A. (2005). Realisasi strategi kesantunan direktif di dalam bahasa Indonesia di kalangan anggota kelompok etnis Minangkabau di Padang (Realization of Politeness Strategies on the Directives in the Indonesian Language produced by members of Minangkabau ethnic group in Padang). (Doctoral), Universitas Indonesia, Fakultas Ilmu Budaya,

Márquez Reiter, R., Ganchenko, K., \& Charalambidou, A. (2016). Requests and counters in Russian traffic police officer-citizen encounters. Pragmatics and Society, 7(4), 512539.

Marzouki, M. E. (2015). Satire as counter-discourse: Dissent, cultural citizenship, and youth culture in Morocco. International Communication Gazette, 77(3), 282-296. doi:10.1177/1748048514568762

Maslo, A. (2016). Using counterfactuals to display facts - the case of satirical humor. ExELL (Explorations in English Language and Linguistics), 4(2), 116-126. doi:10.1515/exell-2017-0010

Matsumoto, Y. (1988). Reexamination of the universality of face: Politeness phenomena in Japanese. Journal of Pragmatics, 12(4), 403-426. doi:10.1016/0378-2166(88)90003-3

Mauri, C., \& Sansò, A. (2011). How directive constructions emerge: Grammaticalization, constructionalization, cooptation. Journal of Pragmatics, 43(14), 3489-3521. doi:10.1016/j.pragma.2011.08.001

Muhidin, R. (2018). Leksikon Kekerabatan Etnik Melayu Palembang (Kinship Lexicons of Palembang Malay Ethnics Group). Ranah: Jurnal Kajian Bahasa, 6(1), 84-99.

Oktovianny, L. (Ed.) (2004) Naskah Kamus Palembang. Palembang: Balai Bahasa Palembang.

Partington, A. (2006). The linguistics of laughter: A corpus-assisted study of laughter-talk: Routledge.

Partington, A. (2008). Teasing at the White House: A corpus-assisted study of face work in performing and responding to teases. Text \& Talk-An Interdisciplinary Journal of Language, Discourse Communication Studies, 28(6), 771-792.

Purnama, H. L. (2008). Makian dalam Bahasa Melayu Palembang: studi tentang bentuk, referen, dan konteks sosiokulturalnya (Cursing in Palembang Malay: a study of form, referent, and its sociocultural context). Sanata Dharma University, 
Ross, A. (1998). The language of humour. London New York: London New York : Routledge.

Rutter, J. (1997). Stand-up as interaction: performance and audience in comedy venues (BL). In: ProQuest Dissertations Publishing.

Rutter, J. (2000). The stand-up introduction sequence: Comparing comedy compères. Journal of Pragmatics, 32(4), 463-483. doi:10.1016/S0378-2166(99)00059-4

Rutter, J. (2001). Rhetoric in stand-up comedy: Exploring performer-audience interaction. Stylistyka X, 307-325.

Schechner, R. (2017). Performance studies: An introduction: Routledge.

Searle, J. (1969). Speech acts: An essay in the philosophy of language (Vol. 626). London: Cambridge university press.

Searle, J. (1976). A classification of illocutionary acts. Language in Society, 5(01), 1-23.

Simpson, P. (2003). On the Discourse of Satire: Towards a stylistic model of Satirical Humour.

Sperber, D., \& Wilson, D. (1995). Relevance : communication and cognition (2nd ed.): Cambridge, MA : Blackwell Publishers.

Trosborg, A. (1995). Interlanguage pragmatics : requests, complaints, and apologies: Berlin New York : Mouton de Gruyter.

Tsakona, V. (2017). Genres of Humor. New York: Routledge, Taylor \& Francis.

Tsui, A. B. (1994). English conversation: Bright Publications.

Wallis, A. (2016). Satire as public discourse in religion. In R. C. Neville, C. H. Evans, D. Jacobsen, A. Speight, \& N. Wariboko (Eds.): ProQuest Dissertations Publishing.

Wehr, H. (1979). A dictionary of modern written Arabic: Otto Harrassowitz Verlag.

Wierzbicka, A. (1985). Different cultures, different languages, different speech acts: Polish vs. English. Journal of Pragmatics, 9(2), 145-178. doi:10.1016/0378-2166(85)900232

Wood, J. R. (2013). Jack Ketch in John Dryden's a Discourse Concerning Satire. The Explicator, 71(1), 60-64. doi:10.1080/00144940.2012.760510

Young Lee, D., \& Ogi, N. (2017). Directive strategies in Modern Korean and Japanese with special reference to commands and requests. In D. Van Olmen \& S. Heinold (Eds.), Imperatives and directive strategies (pp. 248-271): John Benjamins Publishing Company.

Yule, G. (1996). Pragmatics. Oxford: Oxford : Oxford University Press. 